FEATURE

Debra Leaker

Office for National Statistics

\section{SUMMARY}

Unemployment occurs when an individual is available and seeking work but is without work. There are various causes of unemployment, but it normally relates to the economic cycle. When the economy is strong, employers create more jobs and unemployment falls. Conversely when the economy is weak, there is a reduction in job opportunities and unemployment rises.

This article examines unemployment trends using information from the Labour Force Survey and Jobcentre Plus administrative system. It shows trends in unemployment from the early 1970s, and compares the number of people who classify themselves as unemployed with those who are claiming unemploymentrelated benefits. It also looks at the characteristics of unemployed people to describe variations among different subgroups of the population.

\title{
Unemployment Trends since the 1970s
}

T he number of unemployed people in the UK is measured through the Labour Force Survey (LFS) following the internationally agreed definition recommended by the International Labour Organisation.

Unemployed people are those:

- without a job, want a job, have actively sought work in the last four weeks and are available to start work in the next two weeks, or

- out of work, have found a job and are waiting to start it in the next two weeks

\section{Unemployment trends}

The Office for National Statistics (ONS) publishes two different measures of people who want to work but do not have a job.

They are LFS unemployment and the claimant count.

The LFS provides estimates of both the unemployment level and the unemployment rate. The rate is the best indicator because it measures the proportion of the economically active population who are unemployed. This means that it takes account of changes in the size of the population over time, as well as changes in the level of unemployment and movements between economic activity and inactivity.

The claimant count is a count of claimants of unemployment-related benefits, based on the administrative records of people claiming these benefits. Changes to the rules governing entitlement to unemployment-related benefits directly affect the claimant count. This means that changes to the benefit system affect comparisons over time. Using the two sources together provides a more comprehensive picture of the labour market.

Unless otherwise stated, analysis in this article is based on those aged 16 and over.

There will always be a certain level of unemployment, even within a healthy economy, as people enter or re-enter the labour force or move between jobs. This is known as 'frictional unemployment'.

LFS data, which are available back to 1971, show that unemployment follows a cyclical pattern. Figure 1 and Figure 2 show that during the early 1970s, unemployment was relatively low at around 1 million or around 4 per cent of the economically active population. Unemployment increased in the mid 1970s, before levelling off at around 1.5 million (5 per cent) in the late 1970s. Because of the recession in the early 1980s, unemployment rose sharply, peaking at over 3 million (just under 12 per cent) in 1984 . The late 1980s saw an economic recovery, with unemployment falling to around 2 million (7 per cent) before the recession of the early 1990s drove it back up to 3 million (around 10 per cent). Since this peak in 1993, unemployment has decreased gradually to reach levels and rates similar to those last seen in the late 1970s; this trend continued to 2004. The unemployment level and rate for the three months to October 2004 , at 1.4 million and 4.7 per cent respectively, were the lowest on record since 1976. In the three months to September 2008, the unemployment level stood at 1.8 
Figure 1

\section{Levels of unemployment: by sex, ${ }^{1}$ January to March 1971 to July to September 2008}

United Kingdom

Millions, seasonally adjusted

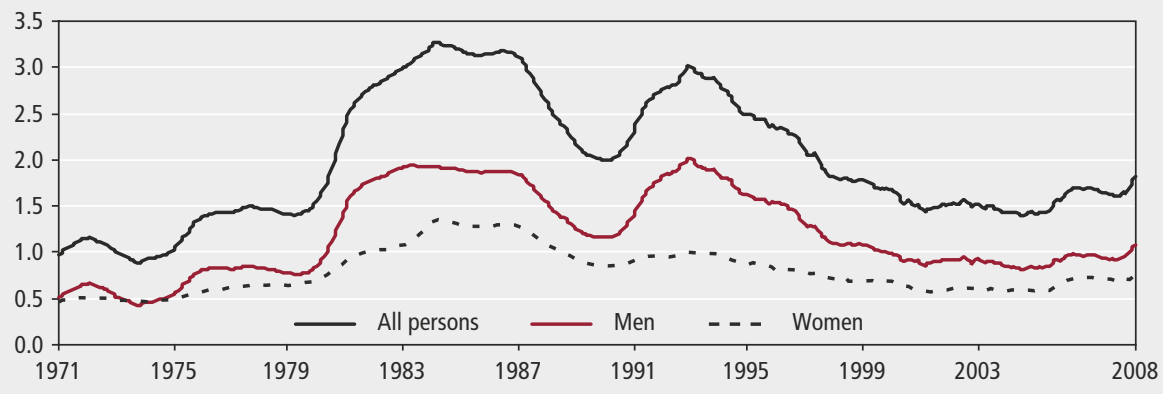

Note:

Source: Labour Force Survey

1 All aged 16 and over.

Figure 2

Unemployment rate: by sex, ${ }^{1}$ January to March 1971 to July to September 2008

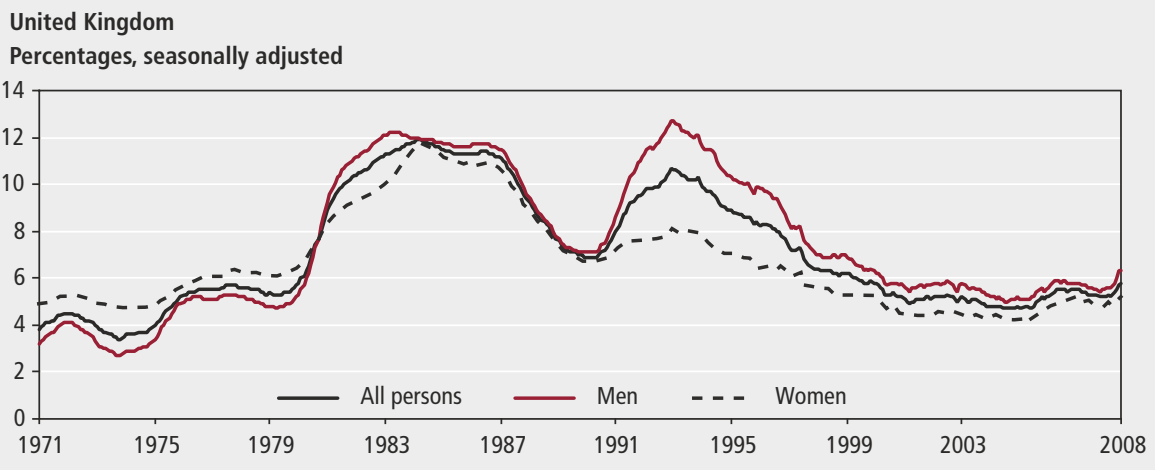

Note:

Source: Labour Force Survey

1 All aged 16 and over. million (up by 182,000 from a year earlier) and the unemployment rate was 5.8 per cent (up by 0.5 percentage points from a year earlier).

Broadly speaking, as the country experiences economic growth, the number of jobs grows and unemployment falls, though any mismatches between the skill needs of the new jobs and the skills of those available for work may slow this process. Conversely, as the economy slows and goes into recession, unemployment tends to rise.

A breakdown of unemployment by duration is available on a seasonally adjusted basis back to 1992. Long-term unemployment, when a person is unemployed for over 12 months, rose to a peak of 1.3 million (44.2 per cent of the unemployed total) in the early 1990s. In the three months to August 2004, the number of people unemployed for more than 12 months was the lowest on record, at 273,000 (19.4 per cent of the unemployed total). In the three months to September 2008, long-term unemployment stood at 435,000.

Trends in the number of people claiming 1990s and has been falling over the last decade. In January 2008, the claimant count was 795,000, the lowest level since 1975 .

Since then, the level has increased to reach 981,000 in October 2008.

Jobseeker's Allowance (JSA) is one of the benefits received by unemployed people. JSA claimant count data are based on information provided monthly to the ONS from the JSA payment system run by Jobcentre Plus. Figure 4 (overleaf) shows that, in October 2008, most women receiving JSA were seeking work in sales and customer service, administrative and secretarial and elementary occupations. Men concentrated their search more in elementary, skilled trades, and process, plant and machine operative occupations.

\section{Characteristics of unemployed people}

Unemployment rates vary among different subgroups of the population in terms of sex, age, location, ethnic origin, disability status, qualification levels, parental status and previous occupation.

\section{Sex}

Unemployment rates for men and women have followed similar cyclical trends, but the recessions of the 1980s and 1990s had a greater impact on men (Figure 1 and Figure 2). The 1980s' recession resulted in a sharp increase in the unemployment rate for men, which overtook the rate for women in the latter half of 1980 and has stayed above it since. In the three months to September 2008, the unemployment rate for men was 6.3 per cent, while the rate for women was 5.2 per cent. However, it is worth remembering the unemployment rate is expressed as a proportion of the economically active population and does unemployment-related benefits have followed a similar pattern to the LFS measure of unemployment, although there are periods of divergence and convergence. Figure 3 shows that the claimant count reached two peaks of around 3 million during the recessions of the mid-1980s and

\section{Figure 3 Unemployment ${ }^{1}$ and the claimant count, February 1971
to October $2008^{2}$}

\section{United Kingdom}

Millions, seasonally adjusted

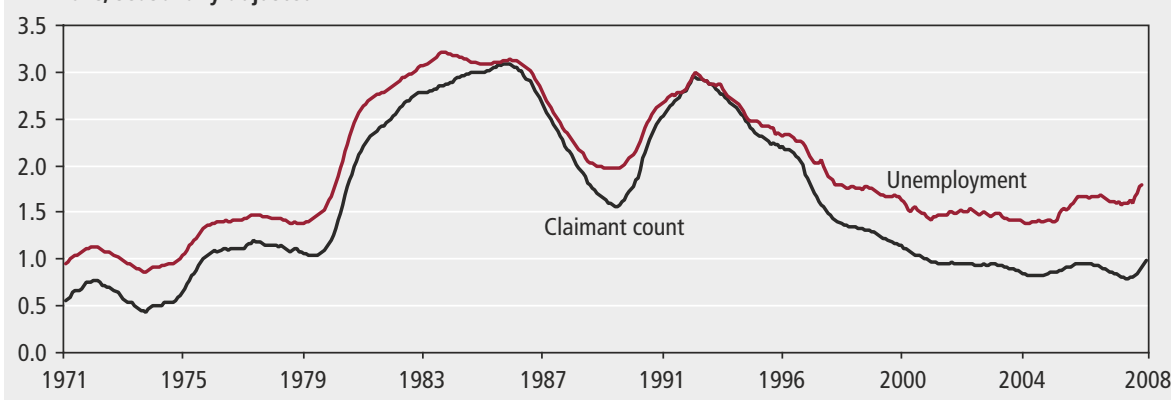

Notes:

Source: Labour Force Survey, Jobcentre Plus administrative system

Men aged 16 to 64 and women aged 16 to 59

2 Unemployment data are only available to August 2008 
Figure 4

\section{JSA claimants: by sought occupation and sex, October 2008}

\section{United Kingdom}

Thousands, not seasonally adjusted

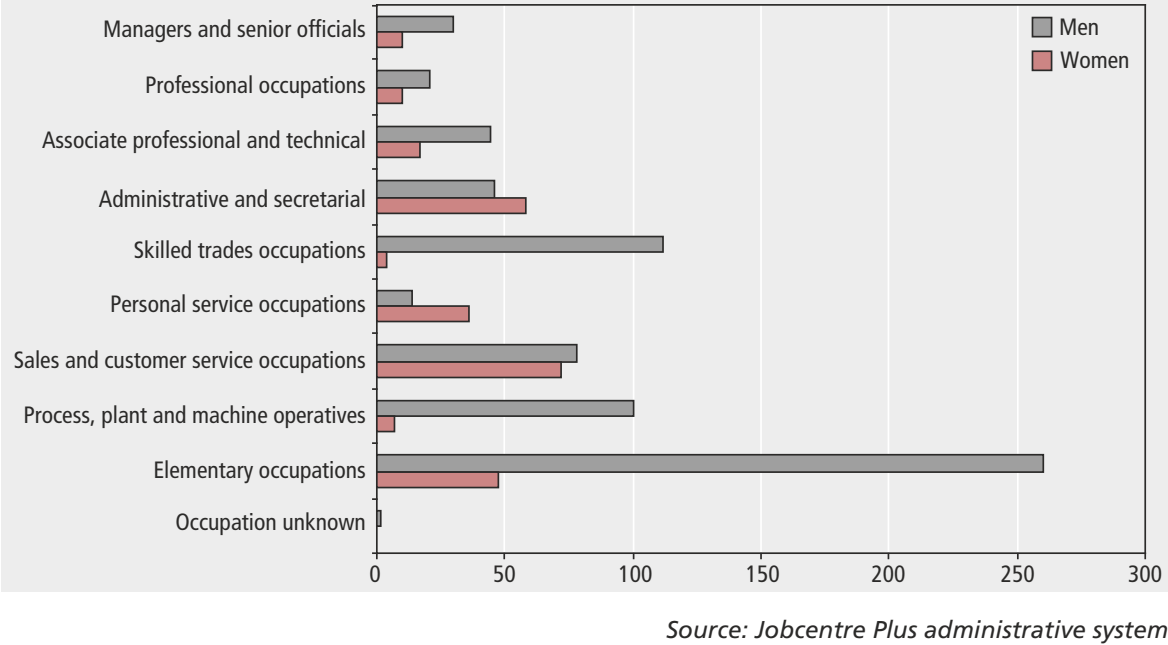

not include those who are economically inactive. Therefore, the unemployment rate should not be used to measure the proportion of a group who are not working as it excludes those who are economically inactive. Although the unemployment rate was higher for men than for women in the three months to September 2008, a higher proportion of women aged over 16 than their male counterparts were economically inactive (43.2 per cent compared with 29.2 per cent)

\section{Age}

Information about unemployment rates by age is available on a seasonally adjusted basis back to 1992. Figure 5 shows that unemployment rates for younger age groups have been consistently higher than those in older age groups. In the three months to September 2008, the unemployment rate for those aged 16 to 17 was 25.7 per cent. This compares with rates of 13.7 per cent for those aged 18 to 24, 4.4 per cent for those aged 25 to 49 , and 3.2 per cent for those aged 50 and over (including those above state pension age).

Figure 6 shows that people aged under 25 account for an increasing proportion of the unemployed total. In the three months to September 2008, some 41.7 per cent of unemployed people were under 25 years old, compared with 30.9 per cent in the three months to September 1992. The group aged 16 to 17 increased from 5.2 per cent of the unemployed total to 10.0 per cent over the same period.

\section{Location}

The Annual Population Survey is derived from the quarterly LFS, but also

\section{Figure 5}

Note:
March 2008. The spread of unemployment rates between these parts of the UK was just 2.9 percentage points between the lowest unemployment rate ( 3.8 per cent) in the South West, and the highest unemployment rate (6.7 per cent) in London. The differences in unemployment rates in local areas within regions are greater than the differences between regions. In the 12 months to March 2008, the region with the greatest contrast between local authorities was London, with 8.1 percentage points between the areas with highest and lowest unemployment rates. The highest unemployment rate was in Tower Hamlets, at 11.7 per cent and the lowest rate was in Richmond-upon-Thames, at 3.6 per cent. The region with the narrowest spread of unemployment rates was the South West, with 3.3 percentage points between the lowest, Purbeck in Dorset at 2.5 per cent, and the highest, Plymouth at 5.8 per cent.

\section{Ethnicity}

As with employment, care must be taken when using ethnicity data for analysis. The different ethnic groups often have

\section{Unemployment rate:' by age group, March to May 1992 to July to September 2008}

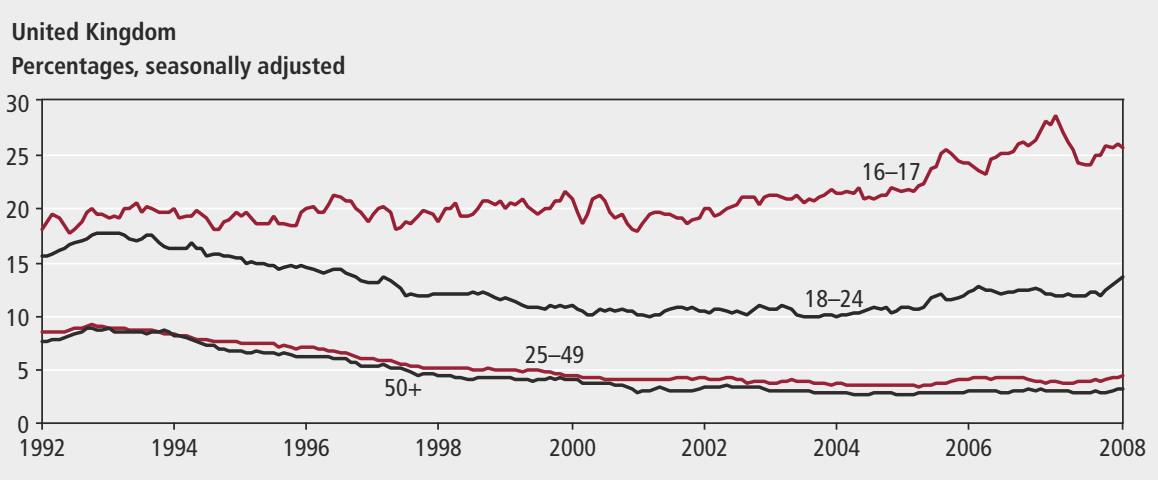

Source: Labour Force Survey

1 Denominator equals all active people in the relevant age group.

Figure 6

Unemployment proportions: by age group, March to May 1992 to July to September 2008

United Kingdom

Percentages, seasonally adjusted

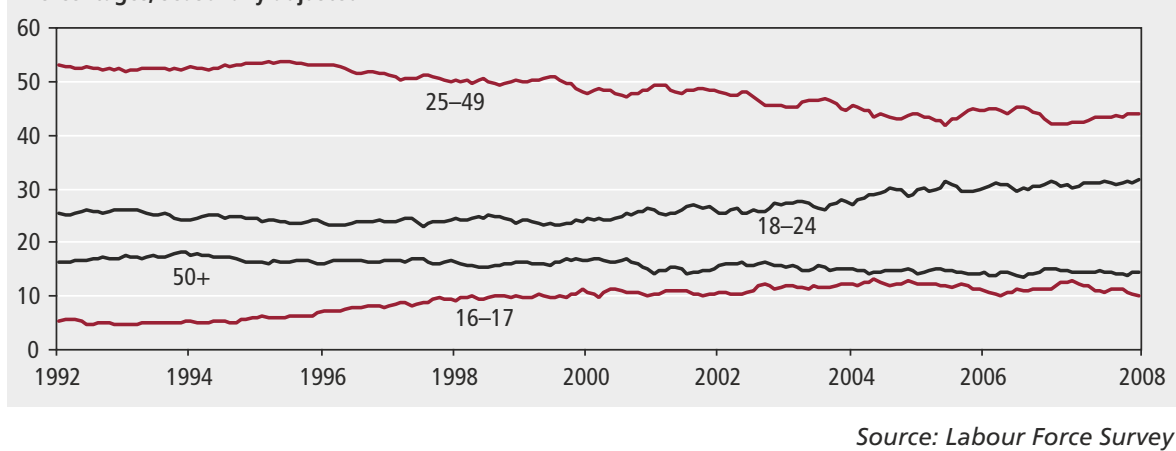




\section{Figure 7}

\section{Unemployment rate: by English region and UK country, ${ }^{1}$ April 2007 to March 2008}

Percentages, not seasonally adjusted

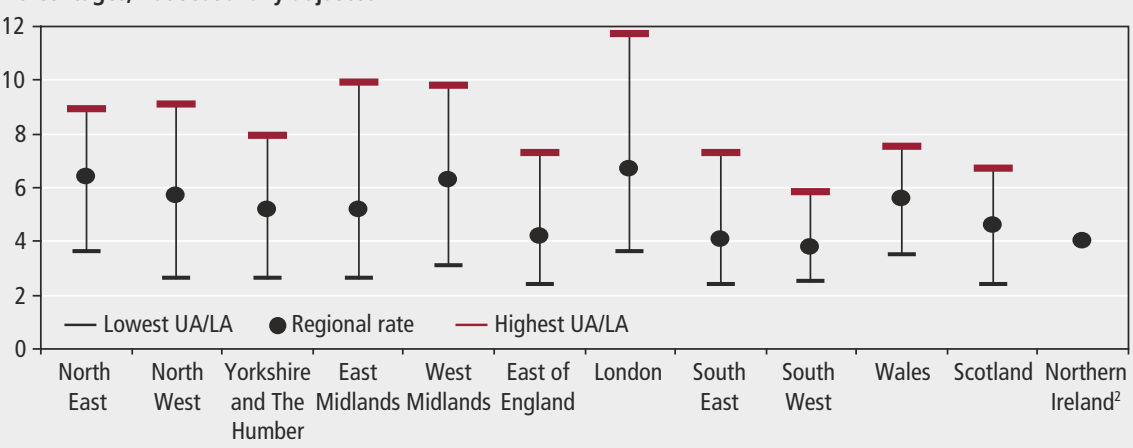

Note:

Source: Model-based estimates, Office for National Statistics

1 These unemployment data for local authorities are derived using a statistical model which takes unemployment estimates from the Annual Population Survey and improves them by 'borrowing strength' from the accurately known administrative data on numbers of Jobseeker's Allowance claimants.

2 Northern Ireland local area data are not available.

different demographics, such as differing proportions of people within each age group. In the three months to September 2008 , the lowest unemployment rates were for people of 'White' ethnic origin (5.6 per cent). Unemployment rates were highest for people of 'Mixed' ethnic origin (14.9 per cent) and the Black or Black British group (14.0 per cent).

\section{Disability}

Unemployment rates are higher among people below state pension age who are long-term disabled than they are for people who are not. Figure $\mathbf{8}$ shows that, in the three months to September 2008, the unemployment rate among long-term disabled people below state pension age was 9.5 per cent, down by 1.5 percentage points from ten years earlier. This compares with 5.8 per cent for those who are long-term disabled, down by 0.2 percentage point from ten years earlier. One-fifth of the unemployed population below state pension age had a long-term health problem or disability (20.1 per cent).

\section{Qualifications}

People with no qualifications are more likely to be unemployed than those with, particularly if these qualifications are at higher levels of educational attainment. In the three months to September 2008, the unemployment rate for people below state pension age with no qualifications was 13.4 per cent. This compares with rates of 5.0 per cent for those qualified to GCE A level or equivalent, and 3.7 per cent for graduates. Around one-sixth of the unemployed population below state pension age had no qualifications (17.3 per cent).

\section{Figure 8} to July to September 2008

United Kingdom

Percentages, not seasonally adjusted

Note:

1 Men aged 16 to 64 and women aged 16 to 59

\section{Figure 9}

United Kingdom

Percentages, ${ }^{3}$ not seasonally adjusted

Notes:

1 All aged 16 and over.

2 April to June quarte. full-time education.

\section{Parental status}

The LFS household datasets have been designed specifically for analysis at the family unit and household levels, and for person-level analysis involving the characteristics of the family unit or household in which people live. Figure 9 shows the unemployment rate for people by parental status for 1998 to 2008 . In the three months to June 1998, the unemployment rate for lone parents was 15.7 per cent, decreasing to 9.1 per cent in the three months to June 2005. Since then, the unemployment rate has risen to 11.8 per cent, the highest rate among the family groups. Married and cohabiting mothers have the lowest unemployment rate, at 3.1 per cent. In the three months to June 2008, the unemployment rate for those without dependent children was 5.6 per cent, down 1.0 percentage points from ten years earlier.

Unemployment rate: ${ }^{1}$ by disability, April to June 1998

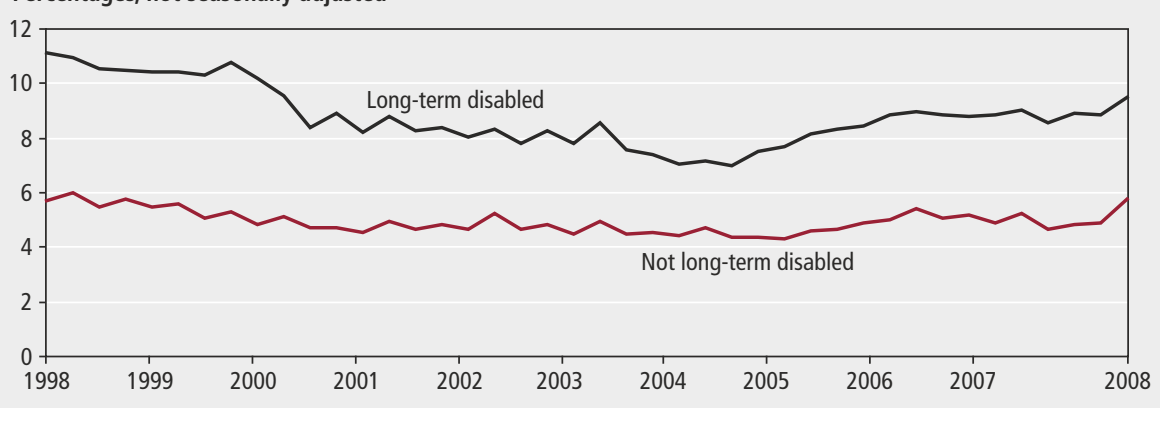

Source: Labour Force Survey

\section{Unemployment rate: ${ }^{1}$ by parental status, 1998 to $2008^{2}$}

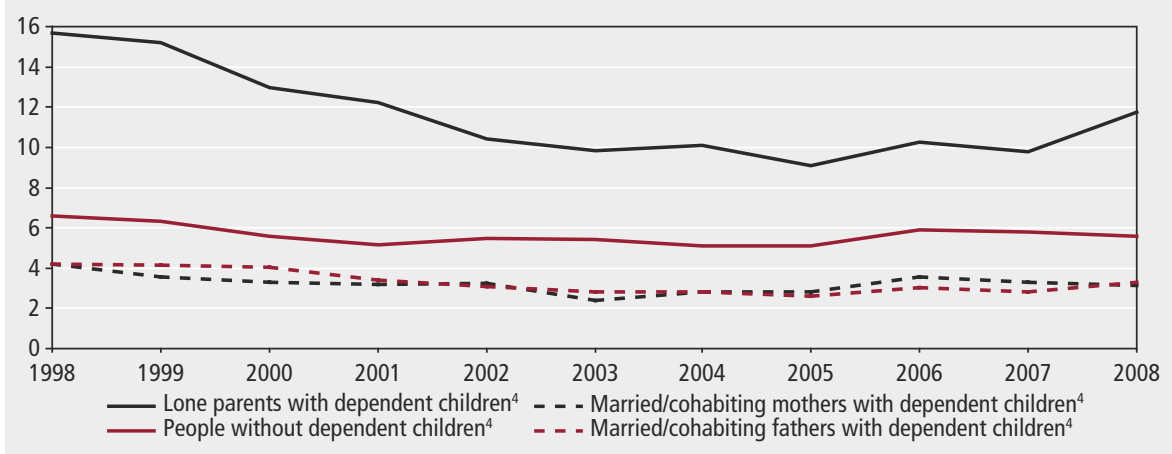

Source: Labour Force Survey Household dataset

3 Base for percentages excludes people with unknown employment status.

4 Dependent children are those under 16 and those aged 16 to 18 who have never married and are in 


\section{Figure 10 \\ Unemployment rate: ${ }^{1}$ by previous occupation, ${ }^{2} 2008^{3}$}

\section{United Kingdom}

Percentages, not seasonally adjusted

Managers and senior officials

Professional occupations

Associate professional and technical

Administrative and secretarial

Skilled trades occupations

Personal service occupations

Sales and customer service occupations

Process, plant and machine operatives

Elementary occupations

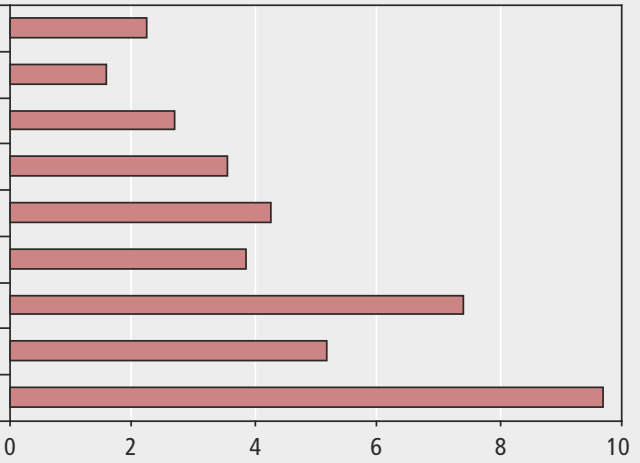

\section{Notes:}

Source: Labour Force Survey

1 All aged 16 and over.

2 Standard Occupational Classification 2000.

3 July to September quarter.

\section{Previous occupation}

The LFS asks unemployed respondents who have worked within the last eight years questions about their last job. This information is used to calculate unemployment rates by previous occupation, as shown in Figure 10. In the three months to September 2008, unemployment rates were highest among those who previously worked in the elementary occupations, at 9.7 per cent. These include hospital porters, bar staff, traffic wardens and cleaners. This compares with Figure 4 where the majority of people claiming JSA were looking for a job in an elementary occupation. Unemployment rates were lowest among those who previously worked in professional and managerial occupations (1.6 and 2.2 per cent, respectively).

\section{Job searching}

The LFS also asks unemployed respondents about the type of work they have been looking for and their main method of job search. In the three months to September 2008, most unemployed people were looking for work as an employee (88.4 per cent), while 2.6 per cent were seeking self-employment, 0.7 per cent were seeking a place on a government employment or training programme and the remaining 8.3 per cent had no preference. Of those who were looking for work as an employee or had no preference over working as an employee or self-employed, most (71.4 per cent) were looking for full-time work or had no preference, while 28.6 per cent were looking specifically for part-time work. Unemployed women were more likely to be looking for part-time work than unemployed men (45.0 per cent and 16.9 per cent, respectively).

The most common method of job search was studying or replying to advertisements in newspapers, journals or on the internet. This was used by 45.9 per cent of unemployed people, while 24.9 per cent visited Jobcentres as their main method, 10.3 per cent applied directly to employers, and 7.3 per cent mainly sought work through friends and relatives.

\section{CONTACT}

elmr@ons.gsi.gov.uk

\section{REFERENCES}

Office for National Statistics Labour Force Survey (LFS) historical quarterly supplement data at

www.statistics.gov.uk/statbase/product. asp? vInk=14365

Office for National Statistics Local area labour market statistical indicators at www.statistics.gov.uk/statbase/product. asp? vink $=14160$

Office for National Statistics UK unemployment levels and rates at www.statistics.gov.uk/statbase/product. asp? vlnk $=8292$

Office for National Statistics Unemployment by age, duration and sex at www.statistics.gov.uk/statbase/product. asp? vlnk $=8272$

Office for National Statistics (Nomis) Further regional and local area labour data at www.nomisweb.co.uk/default.asp 